\title{
THE RELIGIOUS GUIDANCE FOR PROSTITUTE A Descriptive Study at Palimanan Cirebon
}

\author{
Murip Yahya \\ Universitas Wiralodra Indrmayu Jl. H. Ir. Juanda Km.3 Singaraja - Indramayu 45213 \\ Email: murip_yahya@yahoo.co.id
}

\begin{abstract}
This study attempts to investigate the implementation of religious guidance for prostitute and its influence to Woman Social Institution Silih Asih in Palimanan, Cirebon. It formulated on four research questions: 1) How is the process of religious guidance in Social Institution Silih Asib; 2) What is the participants's efforts to achieve the goal of religious guidance; 3) How is the material of religious guidance in Social Institution Silib Asib Palimanan; 4) How is the approach and method of religious guidance applied in Social Institution Silib Asib Palimanan to support and achieve the aim of religious guidance. The study used qualitativenaturalistic, research design with descriptive method. The data were collected through observation, interview, and document analysis. The results of the study show that: 1) there were two stages of religious guidance: identification stage and rehabilitation process; 2) the participants were identified by their age, marital status, education background, parents' job, and reasons of being prostitute; 3) the materials presented on theoretical and natural materials based on Islam thoughts; 4) the religious guidance used various approaches: experience, habituation, emotional, rational, and holistic.
\end{abstract}

Keywords: Religious guidance, Prostitution, Social Institution

\begin{abstract}
ABSTRAK
Penelitian ini betujuan menyelidiki dampak bimbingan keagamaan untuk prostitusi terhadap Panti Sosial Wanita Silih Asih di Palimanan, Cirebon. Penelitian dirumuskan dalam empat pertanyaan penelitian yaitu: 1) Bagaimana proses bimbingan keagamaan di Lembaga Sosial Silib Asih; 2) Apa saja upaya peserta untuk mencapai tujuan bimbingan keagamaan; 3) Bagaimana materi bimbingan keagamaan di lembaga Sosial Silih Asib Palimanan; 4) Bagaimana penggunaan pendekatan dan metode bimbingan keagamaan di Lembaga Sosial Silih Asih Palimanan untuk mendukung pencapaian tujuan bimbingan keagamaan. Metode penelitian yang digunakan adalah kualitatif-naturalistik, desain penelitian bersifat deskriptif. Data dikumpulkan melalui observasi, wawancara, dan analisis dokumen. Hasil penelitian menunjukkan bahwa: 1) ada dua tahap bimbingan keagamaan yaitu identifikasi dan proses rehabilitasi; 2) peserta diidentifikasi berdasarkan usia, status perkawinan, latar belakang pendidikan, pekerjaan orang tua, dan alasan menjadi pekerja seks komersial; 3) materi disajikan secara teoretis dan alamiah berdasarkan pemikiran Islam; 4) Pendekatan bimbingan keagamaan yang digunakan didasarkan pada: pengalaman, pembiasaan, emosional, rasional, dan bolistik.
\end{abstract}

Kata Kunci: Bimbingan keagamaan, Prostitusi, Panti Sosial 


\section{INTRODUCTION}

Islam has illustrated social life problems through Quran and Sunnah. One of them is woman's issue in which Allah SWT has significantly raised woman's position in An-nisa (4: 1-75). In this letter, most of its verses reveal woman's life related to her position, rights, and protection.

Quran, as human's guidance, has thoughtfully placed woman in the right proportion accordance with her position and function in this life. Moreover, Allah Swt creates both man and genie to worship to Him (Al-Dzâriyât: 56, Yunus, 2000: 472) and to be his caliph on Earth to manage everything for the sake of human's welfare (Al-Baqarah: 30, Junus, 2000: 6). Thus, the equal position and different function between man and woman as Allah's servants and Allah's caliphs have changed Islamic Woman's destiny from contemptible to honorable life as God's creation. This condition has raised woman's dignity in fulfilling her function and responsibility.

In addition, another part of Quran also states that there is no differences between man and woman in the form of their genesis and their value of human activities. Based on An-Nisa (1 and 124, Yunus, 2000: 70 and 89) and Al-Imran (195, Yunus, 2000: 69), Allah erases all differences between man and woman especially in humanity.

However, woman's position can also be degraded if she falls into wrong way such as prostitution which becomes one of the problems in human life. Their involvement in prostitution is not only due to the faithless but also some other factors. Hawari (1995: 92) states that life style is as the result of modernisation and the development of science and technology has made the traditional and poor society ignores moral, ethic, and religion values in daily life, including gender value among individuals. Nevertheless, woman's prostitution is mainly due to their faithless.

On the contrary, Simanjuntak and Pasaribu (1984: 201) mentions that there are many factors of prostitution: psychological, economy, social, and biological factors. Letting a lewd activity and free sex become a matter of social distortion since woman sells herself to have a sexual intercourse with any man. Worstly, they do this for the sake of money. In this case, she looses her pride as woman because she does not develop her spiritual aspect and her mind. In line with this, Islam plays an important role to return the prostitues back into their nature and to strengthen their pride not only in social life but also in spiritual life.

Therefore, prostitution as a social issue in the society needs to be solved seriously. According to Kartono (1997: 226), there are three kinds of efforts: preventive, repression, and curative efforts. The preventive effort is realized by prevention activity against prostitution such as confiscation of a porn book or magazine, expansion of job field for woman and improvement citizen's welfare in general. Meanwhile, repression and curative efforts are intended to remove and cure the women from prostitution and direct them into the right path. 
These efforts are realized by localisation, rehabilitation, and educational skill to make them creative and productive.

However, have all those efforts, especially rehabilitation program, succeeded? According to Hull (1997), rehabilitation program gives a less contribution to return the prostitute in the society and to leave her profession as prostitute. In fact, it is not shocking since the income from this sex industry is bigger than other jobs especially for those who have a low education.

Given the above description, it is very important and necessary to reveal the effect of religious guidance to bring round woman especially ex prostitute into her personality in rehabilitation institution. Therefore, this study focuses on religious guidance for ex prostitute in Silih Asib Woman Social Institution in Palimanan, Cirebon. The rehabilitation institution Silih Asib is an institution that attempts to return ex-prostitutes into their real potential and nature as human beings based on religious and society norms. One of the realisations in this institution is through religious guidance program. Furthermore, the most important things is how such program becomes ex-prostitute's biophysicsocial needs.

Besides, the program requires a condusive mechanism and process for exprostitute as the target of self-improvement. However, the problem is how the pattern and process of development are relevent theoretically to educational paradigm especially general education. Thus, the aims of this study is to identify: 1) the process of guidance in Social institution Silib Asib Palimanan; 2) the participant in Social institution Silih Asih Palimanan to achieve the aim of religious guidance; 3 ) the material of religious guidance Social institution Silib Asib Palimanan; 4) the approach and method of religious guidance applied Social institution Silih Asih Palimanan. Furthermore, the study is expected to: 1) give suggestion for the pattern and process of religious guidance toward exprostitutes in rehabilitation institution; 2) theoretically, give a valuable contribution of theoretical framework for the pattern of religious guidance in rehabilitation institution Silih Asib Palimanan, Cirebon; 3) practically, get more significant operational framework as a reference in religious guidance in the institution

This study aims to get objective description of religious guidance for exprostitute in Silih Asib rehabilitation institution in Palimanan, Cirebon. In line with this, the detailed and comprehensive information are needed to learn many phenomena occured during the research. Those phenomena are viewed as special case and holistic study that have relation one to each other in establishing the integrity. Lincoln and Guba (1985: 39) state that the integrity can be understood if it is separated from the context or the situation. This is a non hypothesis research since there is no experiment to test the hypothesis of research question. Otherwise, it attempts to get a new understanding of the studied phenomena. Nevertheless, during the research, it will possibly emerge some hypothesis as guidance or direction for interpreting the data.This study 
attempts to investigate the actual pattern based on emic perspective (based on researcher's point of view), i.e., the subjective opinion and view from the researcher, subjective understanding of other aspect on his or her life, and various kinds of situation and event occured in the setting. Particularly, the researcher tries to undestand the subject based on the fact and opinion. Thus, the data will be in the form of narration-description in words instead of calculation in numbers. It can be conlcuded that this research used qualitativenaturalistic, i.e., a procedural research method that produce a descriptive data in oral and writen form as well as the observation of the subject's behavior. In addition, naturalistic means that the research refers to the natural condition.

This study used descriptive method since the subject of study was limited only to one institution. Besides, the paradigm of this research is qualitative which has the key instrument of the study refers to the researchers himself. In line with this, Lincoln and Guba (1985) mention seven characters to be a qualified instrument of the study. They are responsive, adaptive, and holistic; they have a good awarness toward the context, have an ability to proceed quickly, ability to clarify and summarize tha data fast, ability to explore ideosyincretic answers and have a grounded theory.

The subject is chosen based on the researcher's assumption that the subject has enough information for the research. Some of the subjects refer to the key informant since they have more information. Moreover, the respondent of this study is all of the participants of rehabilitation institution Silih Asib based on snowball sampling technique. Thus, the respondents of this research were ten people. In short, the subject of study includes: a) the participants of rehabilitation institution; b) manager of the rehabilitation institution; c) tutor; d) advisor.

The primary data of this research is from human resources in the form of verbal (response, perception, and subjects' behavior based on their context). Other main data is a phenomena which can give contribution to the investigation based on informant and respondent. Besides the primary data, this research also used nonhuman data as secondary data, i.e document study which analyzed the legal document related to kinds of activities of religious guidance and other written information that gave more information to the obejct of the study.

To get clearer description, it cannot be denied that qualitative statistical data was also important in this research. Meleong (1993:116) mentions that the statistical data can help the researcher to get a clear description toward the subject's tendency during the research. In this context, the use of statistical data was expected to be the evidence of the successful religious guidance program for ex-prostitute in Silih Asih with religious guidance as the main indicator. In the process of data analysis. This statistical data is intrepreted in the form of descriptive information. 
Based on the characteristic of the research, the data collection used into three instuments: observation, interview, and document study. The aim of observation is to monitor the sympthoms occured in the setting including subject's behavior, especially religious and social behaviors. The observation was also conducted to see the religious activities both routine and incidental. The researcher acted as active observer which involved in their activities. By doing such observation, the information can be gained lively and comprehensively especially to know the process, pattern, and material of the religious guidance as the object of the study. This observation was done from 15-30 October 2000. Meanwhile, the aim of interview was to gain some verbal data related to informant's and respondent's perception toward their empirical world. The verbal thoughts, responses, and opinions can be understood easier than body language or expression in the observation. Thus, Nasution (1996: 69) explains that the observation is not sufficient to conduct a reseach. The interview was done in depth based on the guidance questions which have been prepared previously. Thus, the interview will not be out of context. Moreover, to get more valid information, the researcher tried to have a good relationship with the respondents and created a respectful atmosphere as well as trustworthiness. This interview was done from 5 november-15 Desember 2000. Besides two data collection techniques above, this research also used document study including the study of legal document, files, photos, guidance book for operational technique and many more. The quantitative data was by accident collected especially only the available data. The document study is very useful to study the misobserved data or the things that cannot be remembered by the informant. In addition, Nasution (1996: 86) states that document can give more wide information for the object of research and it can be a triangulation data to check the appropriatness of the data. This document also can assist the researcher in analyzing and interpreting the data.

\section{FINDING AND DISCUSSION}

\section{The implementation Rehabilitation Process of Religious Guidance in Woman Social Institution Silih Asih in Palimanan Cirebon}

There were some steps of implementation in rehabilitation process in Woman Social Institution Silib Asib Palimanan Cirebon. First is identification stage or diagnostic period. In this stage, the client was accepted from Social Department or the district social department of West Java Province. This stage has several activities such as the admission and selection of admission for client candidate to determine the fit and proper of client to be accepted as the participant in the rehabilitation institution based on the requirement; identification stage or diagnostic period; revealing data period and problem analysis to analyze and to know her background problem; general orientation period in which the client recognizes various kinds of field both theoretical and 
practical so that the client was expected to choose dynamic skill; and physical cure treatment in which the client was given a routine medical treatment in the local clinic. Second is rehabilitation. In this stage, the client was directed into many study programs through various therapies. The rehabilitation program had some material including mental, physical, social, and skills rehabilitation.

\section{The General Description of Clients in Social Institution Silih Asih}

Tabel 1 to 5 show a general description of participants in Social Institution Silih Asib of 42nd generation. Particularly, the information is classified into age, marital status, level of education, their parents' occupation, and other reasons that made them work as prostitute.

Table 1 Age

\begin{tabular}{|c|c|c|c|}
\hline No & \multicolumn{1}{|c|}{ Age } & Total & Percentage (\%) \\
\hline 1. & 15-19 year & 28 & 27,2 \\
\hline 2. & $20-24$ year & 30 & 29,1 \\
\hline 3. & $25-30$ year & 25 & 24,3 \\
\hline 4. & $31-35$ year & 20 & 19,4 \\
\hline \multicolumn{2}{|c|}{ Total } & $\mathbf{1 0 3}$ & $\mathbf{1 0 0}$ \\
\hline
\end{tabular}

Source: Data from Woman Social Institution Silih Asib Palimanan

Table 2 Marital Status

\begin{tabular}{|c|lc|c|c|}
\hline No & \multicolumn{2}{|c|}{ Marital Status } & Total & Percentage(\%) \\
\hline 1. & Single & 28 & 27,2 \\
\hline 2. & Married & 32 & 31,1 \\
\hline 3. & Widow & 43 & 43 \\
\hline \multicolumn{2}{|c|}{ Total } & $\mathbf{1 0 3}$ & $\mathbf{1 0 0}$ \\
\hline
\end{tabular}

Source: Data from Woman Social Institution Silih Asib Palimanan

Table 3 Education Background

\begin{tabular}{|c|l|c|c|}
\hline No & \multicolumn{1}{|c|}{ Education } & Total & Percentage(\%) \\
\hline 1. & Illiterate & 12 & 11,6 \\
\hline 2. & Elementary school (Unfinished) & 32 & 31,1 \\
\hline 3. & Elementary School & 28 & 27,2 \\
\hline 4. & Junior high school (1-3 grades) & 10 & 9,7 \\
\hline 5. & Junior high school (finished) & 7 & 6,8 \\
\hline 6. & Senior high school (1-3 grades) & 7 & 6,8 \\
\hline 7. & Senior high school (finished) & 7 & 6,8 \\
\hline \multicolumn{2}{r|}{ Total } & $\mathbf{1 0 3}$ & $\mathbf{1 0 0}$ \\
\hline
\end{tabular}

Source: Data from Woman Social Institution Silih Asib Palimanan

Table 4 Parents' Occupation

\begin{tabular}{|c|l|c|c|}
\hline No & \multicolumn{1}{|c|}{ Pekerjaan Orang Tua } & Total & Percentage(\%) \\
\hline 1. & Pension & 2 & 1,9 \\
\hline 2. & Businessman & 7 & 6,8 \\
\hline
\end{tabular}




\begin{tabular}{|c|c|c|c|}
\hline No & Pekerjaan Orang Tua & Total & Percentage(\%) \\
\hline 3. & Trader & 10 & 9 \\
\hline 4. & Farmer & 57 & 55,3 \\
\hline 5. & Labor & 21 & 20,4 \\
\hline 6. & Driver & 1 & 1,0 \\
\hline 7. & Others & 5 & 4,9 \\
\hline \multicolumn{2}{|r|}{ Total } & 103 & 100 \\
\hline
\end{tabular}

Source: Data from Woman Social Institution Silih Asib Palimanan

Table 5 Reasons for being Prostitutes

\begin{tabular}{|c|l|c|c|}
\hline No & \multicolumn{1}{|c|}{ Reasons } & Total & Percentage(\%) \\
\hline 1. & Financial problem & 62 & 60,2 \\
\hline 2. & Psychology & 4 & 3,9 \\
\hline 3. & Dissapointment & 19 & 18,4 \\
\hline 4. & Environment & 18 & 17,5 \\
\hline \multicolumn{2}{|c|}{ Total } & $\mathbf{1 0 3}$ & $\mathbf{1 0 0}$ \\
\hline
\end{tabular}

Source: Data from Woman Social Institution Silih Asib Palimanan

\section{The material of Religious Guidance in Social Institution Silih Asih}

Based on the document study, the material of religious guidance in Social Institution Silib Asib for ex-prostitute was categorized into two classifications. First is theroretical material, including reading and writing Quran; memorizing the praying's incantation; memorizing short verse and pray; fiqh; morals; faith and life after death. Second is natural material such as five times of congregation praying, reading Yâsin and tablîl/dzikikir, tabajjud (sunnah midnight Praying), sunnah fasting on Monday and Thursday.

Besides those materials, there was also another guidance material given in the Islamic Days or based on particular themes. This kind of material was explained directly by the preachers by using emotional approach (feeling), rational (reason), functional ( function in praying), and habituation or exemplary.

For the religious guidance in the form of practical and theoretical guidance, the implementation was held in eight days except the natural activity which was done everyday or everynight such as congregation praying or sunnah fasting. Otherwise, the theoretical religious development was directly scheduled in particular day and time. For example, the material for reading and writing Quran was scheduled every Monday-Tuesday at 18.15 to 19.15; memorizing praying's incantation was held every Wednesday from 18.15 to 19.45; for tablil or dzikir and Yâsin were done at 18.30-19.00. Meanwhile, the material given directly by the preachers was scheduled on Friday from 9.30-10.15 and from 18.3019.15. Moreover, the material for memorizing pray and hifdzul Qur'an was on Saturday from 18.15 to 19.00. Next, the material for Fiqh and morals was scheduled every Sunday from 18.15 to 19.15 . 


\section{The Approach and Method of Religious Guidance Applied in Social Institution Silih Asih}

The religious guidance used several approches. First is experiential approach applied by the preachers and the tutors to set up religious values through experience. Such approach application in this social instituation was precise because the ex-prostitute was asked to contemplate and consider her past experience. Next is habituation approach which was not only applied in the religious development but also in all activities such as in congregation praying, reading Quran, midnight praying, Monday and Thursday fasting. The tight schedule of religious activities aimed to make the ex-prostitutes accustom to be more religious so that it was expected that when they left this social institution, they can do something postive and useful for their lives. Another approach is emotional approach which was intended to analyze the ex-prostitues' emotional condition. Through this approach, it was expected that the they can realize their life and destination. Basically, such approach was applied in the faith and drikir materials. Practically, this approach used riyâdhah or training method such as dzikir an contemplation. Besides, according to the observation, this social institution also applied rational approach for the materials related to the holy and healthy spirit. This approach has purpose to give understanding of religion and to use reasonable mind. For example, mind will accept Allah's command and prohibition such as forbidden free sex or prostitution since this kind of activity had bad impact for their health. Last is holistic Approach which is intertwined with other approaches. For example, the material for praying is not only used habituation approach but also it is supported by rational, experience, and other approaches so that the ex-prostitutes can understand Islam completely and integretedly.

There were some methods used in the religious development to return the ex-prostitute back to their position and to cure their qolbu. The methods are as follows:

a. Lecturing and discussion method

Every Firday from 9.30 to 10.15 and 18.30 to 19.15, all members of Social Institution Silih Asih got a religious preach. This activity used lecturing and discussion method. The content was to give advise, guidance and warning of Islam doctrine. After the preach, the ex-prostitute may have a discussion or ask some questions. This kind of method was also used in Islamic Day commemoration.

b. Iqra Method

Iqra method was used related to reading and writing Quran activity in Social Institution Silih Asib Palimanan Cirebon. Formally, this activity was scheduled every Monday and Thursday but it can be done every night or anytime. This method was especially applied for those who have not read Quran yet. Meanwhile, for some members who can read it well, they can continue to the next level of reading guided by the trainer and tutor. 
c. Drikir Method

There was also drikir method to cure the ex-prostitute mentally. This method aimed to remember Allah. In particular, this method was applied every Thursday at 18.30 to 19.00 in the form of "Tablîp" and "Yâsin".

In addition, dzikir was also applied after congregation praying. It was expected that they can strenghten their faith only to Allah and to emphasize that human really depends to Allah as their khalîl.

d. Training Method/Riyâdhah

The method which was used to cure and to return the ex-prostitute into her position was called training method. Particularly, they must memorize the praying's incantation and short Surah from Quran. This method was intended to make the members apply the incantation in every praying. It was also expected that they accustomed to do useful activity especially in their tasks and obligations. In other words, through this continuous training, the hard things can be done easier.

e. Targhî̉ Method (to do good things) and Tarhî̉ (Intimidation method)

The trainer also applied suggestion and persuasion. For example, they attempted suggest the member that if she did a good things, she would get something delighful. Otherwise, they also tried to intimidate the member with awful torment given from Allah if she made a mistake or violated Allah's rule. This method has a purpose to give motivation for the exprostitutes to do good things and to leave the past habitual, i.e., violating Allah's rule through prostitution.

f. Shalat

Another method was through praying and increase after prayings's intactation. Shalat became a method or therapy to cure the ex-prostitute. In this social institution, all women must do congregation praying and sunnah prayings: pre and post obligatory prayings as well as midnight praying.

\section{The influence of Religious Guidance for Ex-Prostitute in Social Institution Silih Asih}

a. First Respondent (R1)

1) Identity

R1 was eighteen years old and born in Ciamis. Her parents lived in Bandung and they were food seller. In Ciamis, R1 lived in her parents' house with her sister and a little brother. To fullfil their needs, they received money from their parents. R1 admitted that it was enough to fullfil their daily needs. R1 finished her study in elementary school and continued to Islamic boarding school for one year.

2) The reasons of being prostitute

In 1998, there was unforgettable experience in her life, i.e., she was rapped. This occured when she and her friend were asked by some young men to stay at night in certain region. According to her story, she 
was treated a kind of drink "sprite" which had been mixed with particular drug and made her lose her consciousness. After that incident, R1 was shocked and she consumed drugs for a week to forget that incident.

A year later, she had a relationship with a soldier. To be a wife of soldier was her obssession since she was a little kid. That relationship, finally, made R1 pregnant. When she asked her boyfriend to be responsible, he refused and insulted R1 with painful words. R1, then, decided to abort her two months fetus.

The bitter and pain life sent her to the prostitution world. She said that:

"I realize that this job makes me have a big sin. I've already known this in Islamic Boarding school. I did this because I was weak, I can deny this reality."

According to his admission, she did her job to get satisfaction. She used to be extravagant with money that she got form prostitution. R1 did prostitution more or less for four months before she got raid in Cirebon.

3) Her feeling after the process of guidance

When she joined the social institution Silih Asih, she admitted that she was not afraid at all because she had a hunch that she would get caught in the raid operation. In fact, she was grateful to stay there. She was, actually, intended to leave prostitution and try a new life in Ciamis to continue her education in Islamic boarding school. R1 admitted that she had a good relationship with her friends in Silib Asib. She is an easy going person so that many people like her.

R1 liked to stay there since she got many kinds of useful skills that can be used when she would leave the social institution and began her life in the middle of society. She chose processed food skill based on her interest and intention to sell her own food later. She followed all mental spritual development activities well such as congregation praying, religious preach, reading and writing Quran, and many others. She was contend to do congregation praying because she believed that she would get a double reward instead of doing individual praying. The unforgettable preach was related to disobidence, rebellious against parents, and afterlife.

b. Second Respondent (R2)

1) Identity

R2 was born in 1965. Based on the observation, she was called "teteh". This indicates that she was the oldest member in the social institution. R2 has three children. She was divorced with her husband a year ago. After her divorce, she and her children returned to her parents' house in Jatiwangi. Her father worked as a labor in roof tile factory in that region. 
According to her admission, she came from faithful and religious family. R2 only studied until elementary school.

2) The reason of being prostitute

R2 did the prostitution for about five months before she got cought in the raid operation in Kadipaten. She did this because of economy factor. According to her, she was sad that her old father still afforded her mother, herself, and her children. Previously, she decided to sell "lotek", "gado-gado", and snacks to aid her family's financial. Unfortunately, her small business was no longer survived because of the limited fund. That is why she decided to do prostitution. Her parents did not know it. They just knew that R2 worked in convection factory in Bandung. After R2 lived in the social institution, her parents finally knew her real job. Her parents cried and regreted as $\mathrm{R} 2$ revealed:

"I really regret to do this job and I hope that my children and grand children do not the same things like myself."

3) Her feeling after the Process of Guidance

When she stayed in the social institution for the first time, she felt afraid. She thought that something bad would happen to her life. Moreover, she heard that such kind of institution was just like a hell for prostitute. However, after more than a week, that feeling was disappeared little by little. In fact, that feeling was changed into safety, peacefullness, and happiness. It emerged when she found a hospitality, affection, and attention given by the staff especially the trainers. She chose embroidery skill based on her intention to work in convection factory if she would leave the institution. In addition, she felt that the religious guidance gave many benefits for herself, for example reading and writing Quran. Previously, she only read Quran standardly, but now, she could read Quran in the proper way. She got a new knowledge of Tajwid. She also found that the congregation praying gave her multiple reward from Allah and also made her to do the right prayers. She also understood almost all religious preach.

c. Third Respondent (R3)

1) Identity

R3 was one of the members of Social Institution Silib Asib Palimanan. She was the oldest child from six siblings in her family. R3 was from Darmawangi village, Tomo Sub-District, Sumedang Regency. Now, she was 32 years old, born in 1968. R3 admitted that she finished her study until elementary school but she could not read yet. R3 has two children from two marriages. Her first marriage occured when she was sixteen years old but it only stayed for three years and she divorced. She married 
again and had a second child. She was the second wife but finally she got divorced again.

2) The reason of being prostitute

Based on the interview, R3 told that she did prostitution for three years. She reaveled some reasons why she did it:

First, it was due to economy factor since her mother has passed away ten years ago and her father did not have fixed job as a labor which must afford her sister and brother too. R3 admitted that her mother forbid her to be involved in prostituion but she did not listen to her mother's advice since she could not stand with the financial problem.

Second, another factor was because of her second marriage. Her exhusband always left her and stayed with his first wife. Worstly, he had non permanent job.

Third, R3 felt confused to afford her children. Her first child from her frist married was left by his father to Sumatera and her second child was left by his father too. That's why, R3 did prostitution.

Fourth, R3 was mentally dropped when she got her second marriage as the second wife. She was not happy and she felt that marriage was only a burden for her life. This reason made her to be prostitute.

3) Her feeling after the Process of Guidance

During she stayed in the social institution, R3 said that she was not only given a skill but also religious and mental guidance materials. She also mentioned some of materials that she had already learnt such as praying guidance, read Quran with Iqra method, Yâsin every Friday night, religious preach, tabajjud and dluba prayings, Monday and Thursday fasting. Those religious materials have raised her feeling. She felt that those materials changed her point of view and life. She became closer with Allah and felt peaceful. She said: "Since I stay bere, I realized that the religious materials touch my feelings and my life."

4) The influence of the guidance

After three months in this social institution, R3 told her experience. She mentioned that this religious development direct her into the right path and it was useful for her life. She found herself as a woman, mother for her children, as well as she increased her faith and skill.

She also expected not to be back into prostitution. She planned to sell and open a beauty salon. She would pay attention to her children's education and would raise her children which still stayed with her father. She also promised that she would hold her religion guidance and direction tightly. R3 was accustomed to pray, to do Monday and Thursday fasting which she never did before. 
d. Fourth Respondent (R4)

1) Identity

R4 was from Gebangadung, Krangkeng Sub-District, Indramayu Regency. She was still young since she was ninteen years old, born in 1981. She looked innocent and shy. She finished her study until elementary school. R4 admitted that she still had parents which were labors. Now, she stayed in Anggrek dormitory with her twelve friends.

2) The reason of being prostitute

R4 was a little bit introvert respondent so that there was no much information from herself. However, it was revealed that she was brought by the police officer on Friday's night to this social intitution. At that time, she admitted that she was with her partner and they hanged out on the road by playing the guitar. Actually, R4 did not want to admit that she was a prostitute. As she said that after her husband's death, she never wanted to be a prostitute. However, the social instituion Silih Asib did a process and selection of recruitment based on the proper rules.

3) Her feeling after the Process of Guidance

Whatever the reason is, now, R4 felt that she got a wisdom from this incident although she was forced in the beginning. According to her information, she learned many things in this social institution. She admitted that she had learned religious materials such as praying guidance, reading Quran, listening to preach, Monday and Thursday fasting habituation, skill training, tahajud and sunnab praying. The most unforgettable moment was when a preacher explained religious material that can raise her feeling so that she realized her sin and did not want to do it again. Moreover, R4 told that this religious guidance gave influence such as to be back into the right path, to get married with the right husband, to get more religious guidance and general education.

e. Fifth Respondent (R5)

1) Identity

R4 was born in Kedawung, Cirebon in 1980. She finished her study at junior high school and still have parents. She said that she was the only child of her family. Now, she has two years old boy who lives with her husband. She has not legally divorced yet with her husband.

R5, twenty years old, said that she became dilligent to do fasting especially Monday and Thursday. She worked in Indramayu as a salesclerk and stopped to work when she got married. This young lady told that she often went to the library in this social institution.

2) The reason of being prostitute

In the interview, she revealed that she had married and had one son. When she got divorced, she was burdened by her two years old son. R5 
said that she was a prostitute for five months before she was brought to this insttitution. From her statement, there were some reasons why she became a prostitute, among others:

a) Financial problem to fulfil her needs since R5 became her parents' expectation who worked unpermanently.

b) Being left by her husband made her mental burden worst. When she hoped for happines from her husband, she could not find it. In fact, she felt unclear status with her husband now.

c) Her two year old son burdened her life since she must buy milk, clothes, and medicine for her son. In this condition, she said that: "No woman can stand with the child left by her father without any responsibility who still needs more fund since the child is often ill." Those three reason made her become a prostitute which she never knew it before but because of the condition, she was forced to do this kind of job.

3) Her feeling after the Process of Guidance

R5 is one of extrovert respondents. She told her experience with full of enthusiasm. She said that she got many skills and religious knowledge. The materials of religious guidance, such as faith which explains Allah's mighty and Allah's oneness, moral such as hospitality, a proper manner as a wife, etc., guidance for obilgatory and sunnab prayers, suggestion for fasting such as on Monday and Thursday, Nisf asy-sya'ban fasting, and tahajjud praying, general prayer every Friday and Friday night. She admitted that those materials made her feel tranquality and peacefulness so that she was confident to be back into normal life. In addition, since she joined this Social Institution, she often did midnight praying and read Quran diligently.

This religious guidance made her life change. The emotional, functional and rational approaches have made her principle change. She had more skill and knowledge especially as make up artist to own her beauty salon business. Also, she became more religious. Next, she planned to have a reconciliation with her husband if her husband took her as it was and did the right and proper life.

Based on the information from the respondents, it can be concluded that the participants of Silih Asib Social Institution had different background and reason of being a prostitute but they revealed the similar feeling for the influence of religious development.

Basically, Their background of being a prostitute can be classified into two factors:

a. Internal Factor

Internal factor comes from the participants themselves. It covers:

1) Faithless Factor. Most repsondents had this factor. The religious faith determines someone's life and pattern. In this case, the prostitute's life 
style shows their faithless.

2) Financial factor. As it was studied, most respondents did prostitution due to financial problem. Generally, they admitted that their needs such as food, clothing, house made them do the prostitution. In particular, this economy factor was because they must fullfil their urgent needs. For example, they must buy milk for their babies, or they should afford their sibling's or their parents' needs.

3) Frustration factor Another factor which influenced the respondents to do prostitution was hurted and sensitive feelings. This condition led to dissapointment.

4) Education factor

Poor education background was also forced them to do prostitution. Most respondents did not pass senior high school, in fact, they only finished their study in elementary school level. This condition made them fragile and cannot stand to face the real world.

b. External Factor

External factor emerges from outside the respondents. Based on observation and interview, there were some factors caused prostitution:

1) Marriage factor

Unhappy marriage becomes one of the external factor such as being left behind by their husband, to be second wife, or unclear marital status. This factor is also the trigger of prostitution. Moreover, they must take care of their children without any responsibility from her husband. This condition, indeed, triggered those women frustrated and were stuck in prostitution.

2) Sexual abusement factor

Another factor was sexual abusement factor, particularly, as rape victim. As it happened to R1 who made her frustrated and desparate.

3) Lack of parents' affection

Parents' affection is very important. Some of the respondents lose their parents' affection because their parents were divorced. Then, their parents got married again that had their new children.Thus, they lose their parents' affection.

4) Friend factor

Friend factor also influenced the respondents to do prostitution. Intially, they were interested because of the income from prostitution. They followed their friends who had already done this.

\section{CONCLUSION}

In short, those factors influenced them to do prostitution. Certainly, both factors were interconected one to each other. However, most prostitution occured due to the lack of faith so that they cannot survive from their problems 
in life. Basically, all respondents gave positive responds toward the influence of religious development in Social Institution Silib Asib Palimanan, Cirebon. In brief, the influence can be concluded as follows: 1) They have more selfconfident to continue their life; 2) They get motivation to have a better life; 3) They find peaceful, tranquality, and passion to be more independent such as having their own business; 4) They get more religious and faithful. Thus, the program of religious guidance in Social Institution Silih Asib Palimanan, Cirebon gave a significant influences and positive contribution to the ex-prostitutes. Based on the data intepretation, there are some findings related to the implementation of religious guidance in Social Institution Silih Asih, among others: There is still lack of material development in this program. All of the participants of this social institution got the same material level. Otherwise, some of them have different characteristics which require certain appropriate material. Besides, the materials were not compiled sistematically in the form of curriculum. In fact, the trainers or the preachers developed or prepared the materials by themselves. Another finding is that the tight schedule applied by the social institution which began from 04.30 until 21.00. This condition indicates that the ex-prostitutes could not do any activities outside the schedule. Also, it seems that during the program, their freedom is limited and they get less attention. It is also found that there has not been a maximum effort to monitor the ex-prostitutes after they leave the social institution. Although the institution visits their ex-participants, it does not gurantee that they will not do the prostitution again. This research proposes some suggestions: 1) that the materials and the prayers and drikir approaches need more addtional time. Besides, it is better to have recreative and adventure program so that it will not make the participant bored; 2) The facilities in the social institution must be completed such as adequate library, comfortable dormitory, sport center so that the participant will feel contend and this atmosphere will drive their spirit to learn; 3) It is better for he social institution Silih Asib to have a corporation with related parts in society to reach an optimal success.

\section{BIBLIOGRAPHY}

Mujib, Abdul. 1999. Fitrahdan Kepribadian Islam, Jakarta: Darul Falah.

Tafsir, Ahmad. 1987. Ilmu Pendidikan Islam dalam Perspektif Islam, Bandung: RemajaRosdakarya

------, 1995. Metodologi Program Islam, Bandung: Remaja Rosdakarya.

Bogdan, Robert C. R.S. dan Guba. 1985. Pengantar Metodologi Penelitian Kualitatif, Terj. Arief Furqan, Surabaya.

Hawari, Dadang. 1995. Al-Quran, Ilmu Kedokteran Jiwa dan Kesehatan Jiwa, Yogyakarta: Dana Bhakti Prima Yasa.

Junus, Mahmud. 2000. Tarjamah Al Qurän Al Karim, Bandung: Ma’arif. 
Murip Yahya

Licoln \& Guba. 1987. Naturalistic Inquiry, in Michael J. Dinkin; The International Encyclopedia; Teaching and Teacher Education, Program Press.

Hull, Terence dkk. 1997. Pelancuran di Indonesia dalam Kajian Tekstual dan Konstektual, Jakarta: INIS.

Kartono, Kartini. 1986. Psikologi Wanita, Bandung: Alumni.

------, 1997. Psikologi Sosial I, Jakarta: Rajawali Press.

Meleong, Lexy J. 1993. Metodologi Penelitian Kualitatif, Bandung: Rajawali Press.

Nasution. 1996. Didaktik Asas-asas Mengajar, Jakarta: BumiAksara.

Phenix, H. Philip. 1964. Realms of Meaning, New York: Mc. Grow-Hill Book Company.

Simanjuntak, R. dan Pasaribu, I.L. 1984. Pengantar Psikologi Perkembangan, Bandung: Tarsito. 